\title{
Rapid and sensitive method for detection of Staphylococcus aureus enterotoxin genes in milk sample
}

\author{
Mahantesh M Kurjogi*, Basappa B Kaliwal \\ Department of Microbiology and Biotechnology, Karnatak University, Dharwad, Karnataka, India.
}

\begin{tabular}{l}
\hline ARTICLE INFO \\
\hline Article history: \\
Received on: July 26, 2017 \\
Accepted on: November 13, 2017 \\
Available online: February 17, 2018 \\
\hline Key words: \\
Staphylococcus aureus, \\
Enterotoxin, \\
Mastitis, \\
Food poisoning, \\
Real-time polymerase chain reaction, \\
Milk.
\end{tabular}

\section{INTRODUCTION}

Staphylococcus aureus is a common microflora present on the skin and mucous membrane of cattle. Despite it is the amiable nature, $S$. aureus can turn shrewd and get to be distinctly pathogenic. The pathogenicity of $S$. aureus has been generally announced in cows which were found to overwhelmingly bring out disease like mastitis at any given time [1]. Bovine mastitis can be classified into two types, namely, clinical mastitis and subclinical mastitis. Clinical mastitis is diagnosed by the changes in physical appearance of milk and udder, such as swelling, redness, pain, and raise in temperature of the udder, whereas animals affected with subclinical do not exhibit any gross changes in milk or udder, and hence, the diagnosis of subclinical mastitis is more problematic and can be detected only through laboratory tests [2]. Since the milk appears normal in subclinical mastitis, farmers innocently mix the milk with bulk tank which is transported to the consumer market. However, milk drawn from subclinical mastitis cases also harbors pathogenic bacteria that are responsible for subclinical mastitis. $S$. aureus was identified as a predominant bacteria causing bovine mastitis in this part of the country [3]. Staphylococcus may produce numerous potential destructive variables, like toxins. The enterotoxins produced by $S$. aureus are known to produce gastrointestinal toxins in logarithmic phase of their growth curve [4]. Milk is highly nutritious

*Corresponding Author:

Department of Microbiology and Biotechnology,

Karnatak University,

Dharwad, Karnataka, India.

Email: mahantesh.kurjogi@gmail.com food prescribed for the most vulnerable populations such as infants and debilitated people, therefore, screening of milk for the presence of toxins is vital because Staphylococcal enterotoxins are highly active even at nanogram quantities [5] and even stable at higher temperature and low $\mathrm{pH}$, and also they are resistant to proteolytic enzymes of the gastrointestinal tract, and hence, their activity is retained in the digestive tract after consumption [6]. Consequently, consumption of $S$. aureus contaminant milk may result in Staphylococcal food poisoning (SFP). SFP is intoxication that consequences from the consumption enterotoxin contaminated food [7]. A symptom is self-limiting and usually resolves within $24-48 \mathrm{~h}$ which includes queasiness, vomiting, abdominal cramps, and diarrhea, but rarely it can be severe particularly when infants, elderly, or debilitated persons are concerned [8].

Staphylococcal intoxication is a typical disease which is massively underannounced in the light of misdiagnosis, minor episodes, disgraceful specimen gathering, and false-positive laboratory detailing. The financial measurement of this sickness has expected more importance as individuals who experience the ill effects of this disease are those with no immediate access to individual cleanliness; even a little move in their pitiful salary toward social insurance would likely outcome in extraordinary financial hardship. Regardless of the accessible information on the enterotoxins of $S$. aureus, a successful control methodology is yet deficient. New and rapid method for detection of toxin genes directly from the food sample could be outlined with a specific goal to expand the moderateness of medications against an exceedingly advancing SFP.

Thus, the establishment of a method to detect enterotoxin genes in food sample is of prime importance. However, Nakayama et al. developed 
a rapid and direct detection of SE-encoding genes from food sample using a real-time polymerase chain reaction (RT-PCR) for routine laboratory analysis [9]. In this work, we have used RT-PCR to evaluate the existence SE-encoding genes in S. aureus isolated from subclinical mastitis milk sample; further, Se genes were also directly detected from the subclinical mastitis milk sample. Overall, the method used in this study offers a feasible and effective substitute to the available qualitative test for food samples and thus could provide a valuable asset for the diagnosis of intoxication disease due to food poisoning.

\section{MATERIALS AND METHODS}

The subclinical mastitis milk samples were collected in sterile polypropylene containers from lactating cows of the dairy farms located in premises of Dharwad district and brought to the laboratory. The subclinical mastitis was diagnosed based on the intensity of gel formation in the surf field mastitis test [10]. S. aureus was isolated and identified based on conventional methods like colony morphology gram-staining and biochemical tests. Two strains of $S$. aureus harboring enterotoxin genes were identified in our previous work using PCR analysis [11], and the same isolates were selected in the present study for validation of the enterotoxin genes using RT-PCR. Both the $S$. aureus cultures and milk samples were maintained at $-20^{\circ} \mathrm{C}$ until further use.

\subsection{Isolation of DNA from $S$. aureus}

Isolation of DNA was carried out by safety data sheet (SDS)ammonium acetate method as per the methof of Moore et al. [12]. Bacterial strains of $S$. aureus (SA1 and SA2) grown in tryptone soya broth were used for centrifugation and resuspended in $0.2 \mathrm{ml}$ extraction buffer ( $50 \mathrm{mM}$ Tris- $\mathrm{HCl}, 50 \mathrm{mM}$ EDTA, $250 \mathrm{mM} \mathrm{NaCl}$, and $1.5 \%$ sucrose) supplemented with $50 \mu \mathrm{l}$ of SDS (20\%). The solution was vortexed and stored at $65^{\circ} \mathrm{C}$ for $30 \mathrm{~min}$, further $100 \mu \mathrm{l}$ of 7.5 $\mathrm{M}$ ammonium acetate was added to it and stored at $4^{\circ} \mathrm{C}$ for $15 \mathrm{~min}$. DNA was extracted using 1 volume of chloroform:isoamyl alcohol mixture (24:1) and centrifuged at 10,000 rpm for $5 \mathrm{~min}$. Aqueous phase was collected in a new tube, and double volume of ethanol (96-100\%) was added, shake well, and allowed to stand for $30 \mathrm{~min}$ at $4^{\circ} \mathrm{C}$. Further, centrifugation was carried at $10,000 \mathrm{rpm}$ for $15 \mathrm{~min}$, and dried pellet was dissolved in $50 \mu$ l elution buffer $(10 \mathrm{mM}$ Tris- $\mathrm{HCl}$ and $1 \mathrm{mM}$ EDTA). DNA concentration was determined by UV-1800 spectrophotometer (Shimadzu Corporation), and DNA was stored at $-20^{\circ} \mathrm{C}$ for further use.

\subsection{Milk Sample Preparation for qRT-PCR}

Milk samples was divided into two concentrations for evaluation of sensitivity and reproducibility of the method such as $100 \%$ milk sample, where $100 \mathrm{ml}$ of undiluted milk sample was directly used for the preparation, and $10 \%$ milk, where $10 \mathrm{ml}$ of milk sample is diluted with $90 \mathrm{ml}$ distilled water. DNA extraction from the milk sample was carried out as per the method developed by Nakayama et al. [9]. In this procedure, 1:1 volume milk sample $(100 \mathrm{ml})$ and $0.2 \mathrm{M}$ sodium hydroxide was taken and stored at $37^{\circ} \mathrm{C}$ for $20 \mathrm{~min}$. Further, $200 \mu \mathrm{l}$ of sample was neutralized with $10 \mu \mathrm{l}$ of $3 \mathrm{M}$ sodium acetate ( $\mathrm{pH}$ 5.4) and treated with $1 \mathrm{ml}$ petroleum ether followed by centrifugation at $13,000 \mathrm{~g}$ for $10 \mathrm{~min}$ at $25^{\circ} \mathrm{C}$. The aqueous phase was collected in a fresh tube and used for isolation bacterial DNA by DNA purification kit (Promega). Finally, DNA was eluted in $50 \mu$ sterile distilled water and stored at $-20^{\circ} \mathrm{C}$.

\subsection{RT-PCR Analysis}

Quantitative RT-PCR experiment was carried out to evaluate the presence of enterotoxin genes in $S$. aureus isolated from milk sample, and further, validation of the enterotoxin genes in milk sample was also performed using DNA isolated from milk sample. Gene-specific primers for each of the sequences were designed and tested for their activity at $60^{\circ} \mathrm{C}$ by conventional PCR, and integrated DNA technology was used for designing the primers. The sequence of Se A for forward primer was F-CGGAGTTGGATCTTCAAGCAAG and reverse primer was R-AGTCTGTAGAAGTATCAAACAC, similarly the sequence of Se B for forward primer was F- TATTGCTTATTTCTACACCAACG and reverse primer was R- AACCATGAATTTACTCGATTTG. Different primers were also designed to discriminate putative isoforms. Quantitative RT-PCR analyse was carried out with the SYBR Green PCR Master Mix reagent (Stratagene). All the experiments were performed with two replicates: A reaction mixture of $25 \mu 1$ was used which contains $2 \mu \mathrm{l}$ of DNA (50 ng) diluted 1:50, 0, $4 \mu \mathrm{M}$ of each primer, and 12.5 of $2 \times$ SYBR Green PCR Master Mix according to the manufacturer's instructions. The thermal cycling profile includes initial hot start at $95^{\circ} \mathrm{C}$ for $10 \mathrm{~min}, 95^{\circ} \mathrm{C}$ for $20 \mathrm{~s}, 40$ cycles of $95^{\circ} \mathrm{C}$ for $10 \mathrm{~s}$, and $60^{\circ} \mathrm{C}$ for $30 \mathrm{~s}$. Nuclease-free water was used instead of template for blank and was run along with the sample in the same conditions. After preparation, all the master mixes were tapped and spun properly. 96 wells plate was prepared, and $0.8 \mu 1$ of all the reactions mixtures were distributed in each well. The plate was sealed with the given transparent sealer. The system was switched on and plate setup was prepared, and the lamp was also turned on to get ready or heated. Lamp heating takes approximately $20 \mathrm{~min}$. By the time, the plate was spun at $3000 \mathrm{rpm}$ for $3 \mathrm{~min}$. When the lamp was ready, the plate was kept inside and the reaction was stared. The threshold $\mathrm{Ct}$ values were obtained for each sample was analyzed.

\section{RESULTS AND DISCUSSION}

Quantitative RT-PCR is a laboratory technique based on the PCR, used to amplify and simultaneously quantify a targeted DNA molecule. It allows both detection and quantification of DNA molecule as absolute number copies when normalized to DNA input sample. In the present study, the designed set of primers for RT-PCR analysis was specific to the $\mathrm{Se} \mathrm{A}$ and $\mathrm{Se} \mathrm{B}$ genes of the $S$. aureus. The RT-PCR results were reported as $\mathrm{Ct}$ values, representing the cycle at which fluorescence readings exceed the baseline. $\mathrm{Ct}$ values for each sample are the values giving the number of cycle at which the amplification of that particular gene touched the threshold line. In our previous study, we have amplified Se A and Se B gene and sequenced, and data obtained from sequencing were submitted to NCBI nucleotide database with accession number KR819503 and KR819504, respectively. The Ct value of Se A and Se B genes in SA1 and SA2 isolates, respectively, was 18 indicating a strong positive reaction of abundant target nucleic acid in the sample which confirmed the detection of enterotoxin genes in the $S$. aureus isolated from subclinical bovine mastitis milk sample [Figure 1].

Two different concentrations of milk samples were used to evaluate the reproducibility and sensitivity of the DNA preparation method and its detection by RT-PCR. The Ct value depends on the concentration of template DNA present in the milk sample which is available during extraction process. Higher the amount of template DNA, the lower the $\mathrm{Ct}$ value of RT-PCR. Further, enterotoxin gene expression profile at two different concentrations of milk sample showed that the $\mathrm{Ct}$ value for SeA gene at undiluted milk sample (100\%) was 18 , whereas $\mathrm{Ct}$ value of Se A for diluted milk sample (10\%) was 32. Similarly, the $\mathrm{Ct}$ 
value for Se B gene in undiluted and diluted milk sample was 18 and 24, respectively [Figures 2 and 3]. The observed Ct value of the present

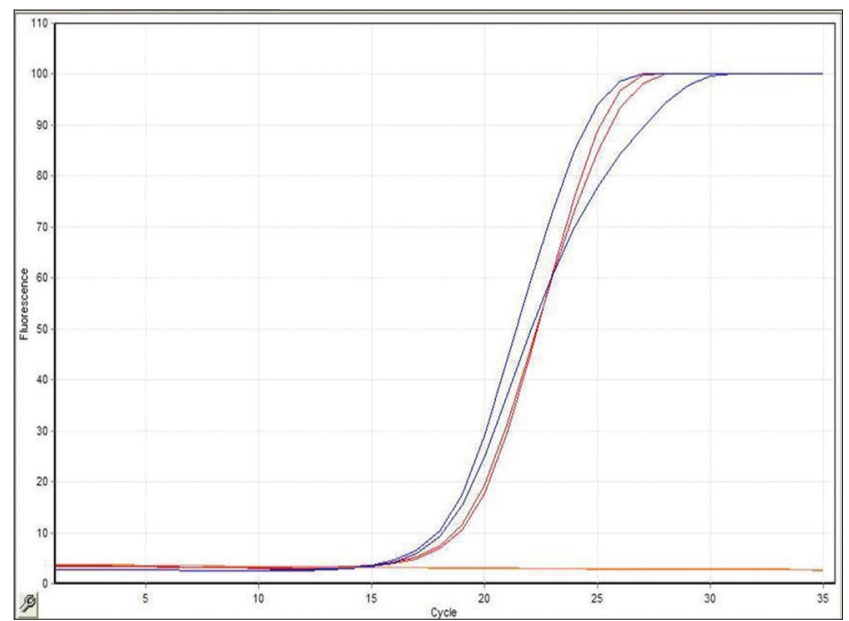

Figure 1: Detection of enterotoxin genes (red line Se A and blue line Se B) in the Staphylococcus aureus.

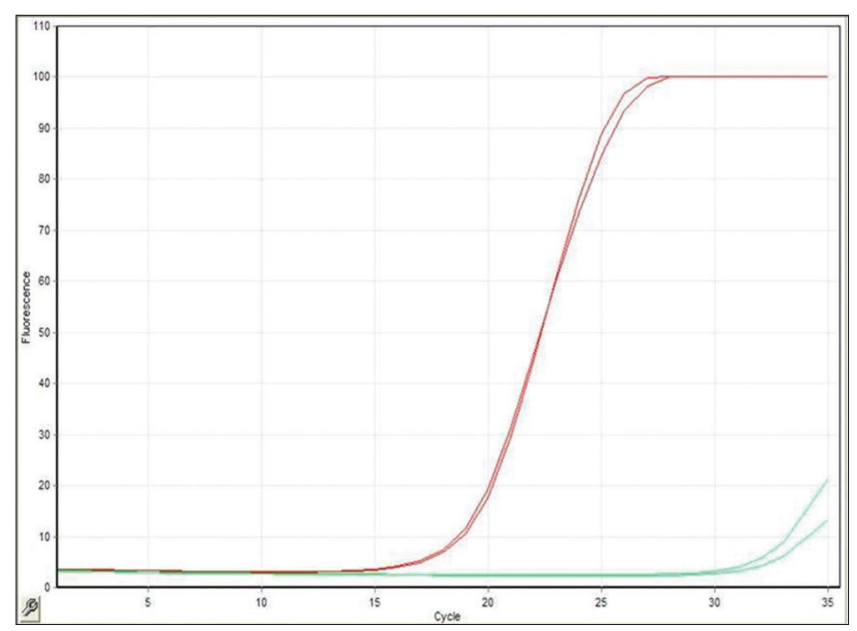

Figure 2: Detection of enterotoxin genes A in milk sample (red line undiluted and green line diluted milk sample).

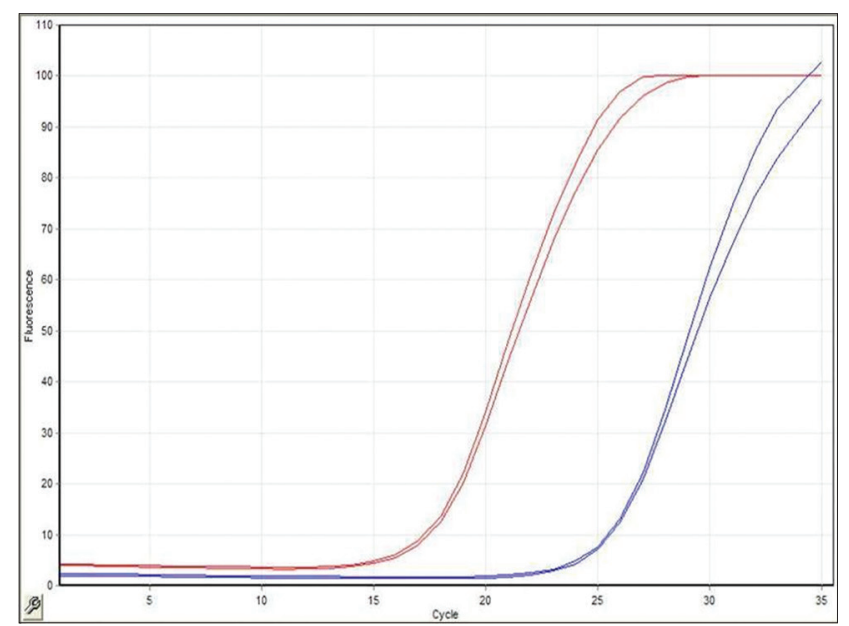

Figure 3: Detection of enterotoxin genes B in milk sample (red line undiluted and blue line diluted milk sample). study revealed that undiluted milk samples harbor abundant target Se A and Se B genes showing a strong positive reactions. However, the $\mathrm{Ct}$ values of diluted milk samples showed a moderate amount of target nucleic acid in the sample representing the state of infection.

Staphylococcal enterotoxin A is one of the common toxins implicated in an outbreak of SFP [13]. The gene responsible for SeA production composed of 771 base pairs nucleotide that codes for enterotoxin A precursor consisting of 257 amino acid residues [14]. There are three isoforms of SeA each carrying different isoelectric points, indicating post-translation modification. The mature form of Se A is 27,100 Dalton which is produced after apparently processing of $\mathrm{N}$-terminal hydrophobic leader sequence [15]. Se $\mathrm{A}$ has a $\mathrm{Zn}^{2+}$ coordination site involved in MHC Class II binding. The coding region of the Se B gene contains 900 base pairs nucleotides that encode the precursor protein containing 267 amino acids with 31,400 Dalton [16].

Mode of action of staphylococcal enterotoxins in gastrointestinal tract showed the stimulation of vagus nerve in the abdominal viscera, which conveys the signal to the nausea center in the brain [17]. In addition, ingested enterotoxins penetrate the gut lining and trigger local and systemic immune responses which releases the inflammatory mediators such as histamine, leukotrienes, and neuroenteric peptide substance resulting in vomiting [18-21]. Activation of local immune system is also responsible for damage of gastrointestinal tract [13]. Further, Se intoxication also damages the upper part of the small intestine; however, inflammatory changes are observed on other regions of the gastrointestinal tract [22]. Sometimes, SEs intoxication leads to inhibition of water and electrolyte in the small intestine, resulting in diarrhea [23]. Superantigenic nature of enterotoxin activity is attributed to transcytosis, which enables the toxin to enter the bloodstream, thus subjected to the interaction with antigen presenting and T-cells that leads to superantigen activity [24].

The RT-PCR used in the present study confirmed the presence of enterotoxin genes in both milk samples collected from the cows with subclinical mastitis cases and $S$. aureus isolated from the same milk. In addition, DNA extracted from the milk sample combined with gene expression by RT-PCR analysis was highly sensitive for detection of enterotoxin Se A and Se B from undiluted and 10-fold diluted milk sample. Similarly, Rajkovic et al. [25] detected Se B gene using RTPCR from food sample, whereas other enterotoxin genes such as Se d, Se e, Se g, Se j, and Se i were also detected in some strains of $S$. aureus [26]. Likewise, reports showed that nine Se genes were detected with universal primers using SYBR green chemistry [27]. The RT-PCR was also used to identify the methicillin-resistant $S$. aureus and methicillin-susceptible $S$. aureus from clinical samples [28]. The past reports from Germany suggest that $\mathrm{Ct}$ for fem $\mathrm{B}$ gene was between 21.8-33.7 and 22.5-33.5 for Se a gene [29]. Nakayama et al. [9] detected eight Se-encoding genes in the $S$. aureus of milk sample, and the $\mathrm{Ct}$ value detection limit of Se encoding gene was between 39.44 and 37.92 .

Since our aim in the present investigation is to evaluate the quality of the milk drawn from the cow with subclinical mastitis, as subclinical mastitis neither shows any symptoms on the udder of cow nor any visible changes in milk. However, the study demonstrated the application of available method for detection of enterotoxin genes in the $S$. aureus isolated from the contaminated milk and also successfully detected the presence of enterotoxin genes in milk sample using DNA isolation method directly from the sample. In the past, Se A was successfully detected in staphylococcal outbreak milk samples by the modified RPLA method [30]. RPLA method used rotary evaporator 
to concentrate the extract of SE from the samples. However, RT-PCR method of direct detection of Se from the sample is more sensitive and rapid than that of RPLA method. Furthermore, the RT-PCR method was also proved to be a successfully applicable technique for direct detection of Se from the clinical samples that contain high levels of PCR inhibitors [9]. Rajkovic also compared iqPCR with inhouse ELISA technique for detecting Se $\mathrm{b}$ toxin genes in both pure culture and contaminated food sample and found that iqPCR was approximately 1,000 times more sensitive than the in-house ELISA method [25]. Similarly, decade ago, Heller used the different available kit for comparing the sensitivity of the methods for DNA isolation from food samples for detection of Shiga toxin-producing Escherichia coli by RT-PCR [31].

Although conventional microbiological methods for identifying pathogenic bacteria from environmental samples are reliable, they require several days to complete. The data reported here suggest that the direct DNA isolation method combined with RT-PCR method has advantages over all of the previously used identification methods in specificity, sensitivity, and cost. This assay allows the detection of an important toxin gene in food and clinical samples. This assay may be useful for the early detection of Staphylococcus food poisoning outbreak. The advantage of RT-PCR over other methods is the time required for RT-PCR analysis is minimum $(<4 \mathrm{~h})$ with reliable results. Besides, conventional PCR methods use ethidium bromide which is a potent carcinogen and required to be strictly regulated and also restricted in the food industries and less common in routine laboratories of many countries. Thus, the use of RT-PCR method is a real improvement from this point of view. In addition, RT-PCR technique provides spontaneous results that eliminate the further processing of the samples which reduce the time-consuming and risk of carry-over contamination.

\section{CONCLUSIONS}

In this study, we have successfully detected the Se A and Se B genes in both pure cultures and also milk samples collected from subclinical mastitis cow. Although all the techniques reported so far in detecting the toxin genes in food sample found significant differences between the study groups, the difference in estimation of enterotoxin varies considerably from one sample to other with reference to geographical locations or ecological origin of pathogenic strains present in the food sample. Nevertheless, the results of the present study support the earlier suggestions with respect to the importance of quality test of milk before reaching the consumer. Overall, the method validated in this study provides a feasible and efficient alternative to the conventional qualitative test for food samples and thus could provide a valuable asset for such food processing industry, for the diagnosis of intoxication disease due to food poisoning.

\section{REFERENCES}

1. Fox LK, Gay JM. Contagious mastitis. Vet Clin North Am Food Anim Pract 1993;9:475-87.

2. Hokmabad RV, Mogaddam MF, Sadegh MM, Mirzaii H. Bacterial pathogens of intramammary infections in Azeri buffaloes of Iran and their antibiogram. Afr J Agric Res 2011;6:2516-21.

3. Kurjogi MM, Kaliwal BB. Prevalence and antimicrobial susceptibility of bacteria isolated from bovine mastitis. Adv Appl Sci Res 2011;2:229-35.

4. Derzelle S, Dilasser F, Duquenne M, Deperrois V. Differential temporal expression of the staphylococcal enterotoxins genes during cell growth. Food Microbiol 2009;26:896-904.
5. Larkin EA, Carman RJ, Krakauer T, Stiles BG. Staphylococcus aureus: The toxic presence of a pathogen extraordinaire. Curr Med Chem 2009;16:4003-19.

6. Evenson ML, Hinds MW, Bernstein RS, Bergdoll MS. Estimation of human dose of staphylococcal enterotoxin A from a large outbreak of staphylococcal food poisoning involving chocolate milk. Int J Food Microbiol 1988;7:311-6.

7. Le Loir Y, Baron F, Gautier M. Staphylococcus aureus and food poisoning. Gen Mol Res 2003;2:63-76.

8. Murray RJ. Recognition and management of Staphylococcus aureus toxin-mediated disease. Intern Med J 2005;35 Suppl 2:S106-19.

9. Nakayama A, Okayama A, Hashida M, Yamamoto Y, Takebe H, Ohnaka T, et al. Development of a routine laboratory direct detection system of staphylococcal enterotoxin genes. J Med Microbiol 2006;55:273-7.

10. Muhammad G, Athar M, Shakoor A, Khan MZ, Rahman F, Ahmad MT. Surf field mastitis test: An expensive new tool for evaluation of wholesomeness of fresh milk. Pak J Food Sci 1995;5:91-3.

11. Kurjogi MM, Kaliwal RB, Shivasharana CT, Kaliwal BB. Characterization of toxin genes in Staphylococcus aureus isolated from milk of cows with mastitis. Int J Rec Sci Res 2012;3:841-6.

12. Moore E, Arnscheidt A, Kruger A, Stromp C, Mau M. Simplified protocols for the preparation of genomic DNA from bacterial cultures. Mol Microb Ecol Man 2004;1:3-18.

13. Holmberg SD, Blake PA. Staphylococcal food poisoning in the united states. New facts and old misconceptions. JAMA 1984;251:487-9.

14. Huang IY, Hughes JL, Bergdoll MS, Schantz EJ. Complete amino acid sequence of staphylococcal enterotoxin A. J Biol Chem 1987;262:7006-13.

15. Betley MJ, Mekalanos JJ. Nucleotide sequence of the Type A staphylococcal enterotoxin gene. J Bacteriol 1988;170:34-41.

16. Johns MB Jr, Khan SA. Staphylococcal enterotoxin B gene is associated with a discrete genetic element. J Bacteriol 1988; 170:4033-9.

17. Sugiyama H, Hayama T. Abdominal viscera as site of emetic action for staphylococcal enterotoxin in the monkey. J Infect Dis 1965;115:330-6.

18. Shanahan F, Denburg JA, Fox J, Bienenstock J, Befus D. Mast cell heterogeneity: Effects of neuroenteric peptides on histamine release. J Immunol 1985;135:1331-7.

19. Scheuber PH, Denzlinger C, Wilker D, Beck G, Keppler D, Hammer DK, et al. Cysteinyl leukotrienes as mediators of staphylococcal enterotoxin B in the monkey. Eur J Clin Invest 1987; 17:455-9.

20. Alber G, Scheuber PH, Reck B, Sailer-Kramer B, Hartmann A, Hammer DK, et al. Role of substance $\mathrm{P}$ in immediate-type skin reactions induced by staphylococcal enterotoxin B in unsensitized monkeys. J Allergy Clin Immunol 1989;84:880-5.

21. Jett M, Brinkley W, Neill R, Gemski P, Hunt R. Staphylococcus aureus enterotoxin B challenge of monkeys: Correlation of plasma levels of arachidonic acid cascade products with occurrence of illness. Infect Immun 1990;58:3494-9.

22. Kent TH. Staphylococcal enterotoxin gastroenteritis in rhesus monkeys. Am J Pathol 1966;48:387-407.

23. Sheehan DG, Jervis HR, Takeuchi A, Sprinz H. The effect of staphylococcal enterotoxin on the epithelial mucosubstance of the small intestine of rhesus monkeys. Am J Pathol 1970;60:1-18.

24. Hamad AR, Marrack P, Kappler JW. Transcytosis of staphylococcal superantigen toxins. J Exp Med 1997;185:1447-54.

25. Rajkovic A, El-Moualij B, Uyttendaele M, Brolet P, Zorzi W, Heinen E, et al. Immunoquantitative real-time PCR for detection and quantification of Staphylococcus aureus enterotoxin B in foods. Appl Environ Microbiol 2006;72:6593-9.

26. Becker K, Friedrich AW, Lubritz G, Weilert M, Peters G, Von Eiff C, 
et al. Prevalence of genes encoding pyrogenic toxin superantigens and exfoliative toxins among strains of Staphylococcus aureus isolated from blood and nasal specimens. J Clin Microbiol 2003;41:1434-9.

27. Letertre C, Perelle S, Dilasser F, Fach P. Detection and genotyping by real-time PCR of the staphylococcal enterotoxin genes sea to sej. Mol Cell Probes 2003;17:139-47.

28. Paule SM, Pasquariello AC, Thomson RB Jr. Kaul KL, Peterson LR. Real-time PCR can rapidly detect methicillin-susceptible and methicillin-resistant Staphylococcus aureus directly from positive blood culture bottles. Am J Clin Pathol 2005;124:404-7.

29. Klotz M, Opper S, Heeg K, Zimmermann S. Detection of Staphylococcus aureus enterotoxins A to D by real-time fluorescence PCR assay. J Clin Microbiol 2003;41:4683-7.

30. Asao T, Kumeda Y, Kawai T, Shibata T, Oda H, Haruki K, et al. An extensive outbreak of staphylococcal food poisoning due to low-fat milk in Japan: Estimation of enterotoxin A in the incriminated milk and powdered skim milk. Epidemiol Infect 2003;130:33-40.

31. Heller LC, Davis CR, Peak KK, Wingfield D, Cannons AC, Amuso PT, et al. Comparison of methods for DNA isolation from food samples for detection of shiga toxin-producing Escherichia coli by real-time PCR. Appl Environ Microbiol 2003;69:1844-6.

How to cite this article:

Kurjogi MM, Kaliwal BB. Rapid and sensitive method for detection of

Staphylococcus aureus enterotoxin genes in milk sample. J App Biol

Biotech. 2018;6(2):15-19. DOI: 10.7324/JABB.2018.60203 